\title{
Handling, Processing, Utilization and Marketing of Ayib (Ethiopian Traditional Cottage Cheese) Varieties Produced in Selected Areas of Eastern Gojjam, Northwestern Highlands of Ethiopia
}

\author{
Aleme Asresie ${ }^{1,2 *}$, Zelalem Yilma ${ }^{3}$, Eyassu Seifu ${ }^{4}$, Lemma Zemedu $^{5}$, Mitiku Eshetu2 $^{2}$ \\ Mohammed Y. Kurtu ${ }^{2}$ \\ ${ }^{1}$ Department of Animal Production and Technology, Adigrat University, Adigrat, Ethiopia \\ ${ }^{2}$ School of Animal and Range Sciences, Haramaya University, Dire Dawa, Ethiopia \\ ${ }^{3}$ PAID Ethiopia, Addis Ababa, Ethiopia \\ ${ }^{4}$ Department of Food Science and Technology, Botswana University of Agriculture and Natural Resources, \\ Gaborone, Botswana \\ ${ }^{5}$ School of Agricultural Economics and Agribusiness, Haramaya University, Dire Dawa, Ethiopia \\ Email: ^almasres06@gmail.com
}

How to cite this paper: Asresie, A., Yilma, Z., Seifu, E., Zemedu, L., Eshetu, M. and Kurtu, M.Y. (2018) Handling, Processing, Utilization and Marketing of Ayib (Ethiopian Traditional Cottage Cheese) Varieties Produced in Selected Areas of Eastern Gojjam, Northwestern Highlands of Ethiopia. Open Journal of Animal Sciences, 8, 51-73. https://doi.org/10.4236/ojas.2018.81005

Received: October 8, 2017

Accepted: December 26, 2017

Published: December 29, 2017

Copyright ( $) 2018$ by authors and Scientific Research Publishing Inc. This work is licensed under the Creative Commons Attribution International License (CC BY 4.0).

http://creativecommons.org/licenses/by/4.0/ c) (i) Open Access

\begin{abstract}
The study was conducted to asses handling, processing, utilization, marketing as well as other socio-economic benefits of traditional cheese varieties making and to identify major constraints of traditional cheese varieties production in Awabal, Gozamin, Machakel and Dejen districts of Eastern Gojjam. A cross-sectional survey was conducted to collect data. A total of 240 smallholder dairy producers (60 households from each district) were individually interviewed using a semi-structured questionnaire. The major traditional cheese varieties produced in the study areas include Ayib, Metata, Hazo and Zureshekefign. Among these, three of them (Ayib, Metata and Hazo), are dominant. Respondents indicated that Metata cheese variety has high nutritional values and cure seven types of disease namely malaria and yellow fever, depressed appetite; Ejeseb (stomach upset), metabolic disorder (bloating), gastro-intestinal parasites, prevent nausea and digestion upset. The respondents reported twenty kinds of spices blended at one time during Metata cheese preparation and five kinds of spices commonly added into Ayib during Ayib making. Various types of herbs and plant species are used for smoking and washing of utensils during production of traditional cheese varieties in the study areas. The major marketing constraints of traditional cheese varieties were absence of sufficient buyer in the market, traditional taboos to sell cheese
\end{abstract}


varieties in an open market, seasonal demand and supply, distance to the market, transportation access and quality. The major socio-economic benefits of traditional cheese varieties were to fulfill household necessities, sources of additional income, to purchase dairy inputs and for children school fee. Further scientific study needs to be conducted in order to confirm nutritional and medicinal properties of Metata cheese variety. Therefore the bio-active components of these spices and their effect on shelf life, nutritional value, medicinal uses and other attributes on traditional cheese varieties needed further investigation.

\section{Keywords}

Ayib, Hazo, Metata, Zureshekefign

\section{Introduction}

Fermented foods are produced worldwide using various manufacturing techniques, raw materials and microorganisms [1]. Fermentation is a widely practiced ancient technology and fermented foods are an essential part of diets of people in all regions of the world. Traditional fermented foods are those that are indigenous to a particular area and have been developed by the local people using age-old techniques and locally available raw materials. The early man probably used short time fermented beverages as a safe substitute for water, since the alcohol content is too low in the early stages of fermentation to produce intoxication [2]. Dairy products such as cheese, yoghurt and sour milk are fermented, protein-rich, have probiotics property and the ability to kill pathogens as well as modulate the immune system [3]. This popularity has made fermented foods one of the main dietary components of the developing world.

The rural communities in Ethiopia produce fermented milk products by traditional methods. The major fermented milk products produced by smallholder farmers in the country include Ergo (fermented sour milk), Ititu (fermented milk curd), Kibe (traditional butter), Neter Kibe (spiced butter), Ayib (cottage cheese), Arerra (sour defatted milk), and Aguat (whey) [4]. Ayib is a traditional cottage cheese made from defatted sour milk by heating the milk on a slow flame to precipitate the casein. Ayib has a shelf life of only a few days and is either consumed at home or marketed [5]. Metata cheese (a traditional spiced blended fermented hard cottage cheese) is an example of such traditional fermented cottage cheese product and it has a long shelf life of up to two years in semi-solid form but ten years when produced in dry form at household level [6]. It differs from the traditional cottage cheese; the production of Metata cheese variety involves the use of different spices and spontaneous fermentation for about 25 days.

The safety of dairy products with respect to food-borne diseases is a great concern around the world. This is especially true in developing countries where production of milk and various dairy products take place under unsanitary con- 
ditions and poor production practices [7].

With regard to marketing, milk and milk products in Ethiopia are channeled to consumers through both formal and informal marketing systems. In the formal system, milk is collected at dairy cooperatives or private milk collection centers and transported to processing plants. The second type is the informal system, which is the dominant system in Ethiopia where milk and milk products may pass from producers to consumers directly or through one or more market agents. As a result, farmers are challenged by price decline for their produce as their supply increases beyond the market size of their village or nearby small town. This in turn diminishes the net value of return from milk and milk products. Market access is becoming a major problem in addition to productivity related constraints. Generally, Ethiopia is said to have a comparative advantage in the production of milk and its derivative with most if not all other neighboring African countries, among others due to its relatively high livestock population and suitable environment for dairy production. This comparative advantage can best be exploited if studies focus on comprehensive approach that encompasses increasing production, quality and marketing of the products.

East Gojjam Zone is an important milk producing area in Amhara National Regional State of northwestern highlands of Ethiopia in general and Awabal, Gozamin, Machakel and Dejen districts in particular. The milk is produced from cow milk, under traditional conditions and processed into different traditional cheese varieties in the study areas such as Ayib, Metata, Hazo and Zureshekefign. Even if the area has potential for production of milk and milk products, little is known about the merits and limitations of the existing milk and milk products handling, utilization and processing methods in order to design development interventions that meet the need of the farmers. Identification of problems and understanding of the existing milk and milk products handling, processing and utilization in the area is the first step in the right direction.

There is inadequate scientific report that addresses the handling, processing, utilization and marketing of traditional cheese varieties in the study areas. To fulfill this gap understanding the properties of these noble traditional dairy products and proper scrutiny of the indigenous manufacturing procedure are important in order to devise appropriate development interventions that would result in an improved method of production, yield and quality. Therefore, it is against this background and justification that this study was initiated to assess the processing, handling, utilization and marketing as well as other socioeconomic benefits of the traditional cheese varieties and major constraints in study areas.

\section{Materials and Methods}

\subsection{Description of the Study Areas}

East Gojjam is a Zone in the Amhara National Regional State of Ethiopia. East Gojjam is named after the former province of Gojjam. It is borders the Oromia 
National Regional State in the South, West Gojjam Zone in the west, South Gondar in the north, and South Wollo in the east. The bend of the Abay River defines the Zone's northern, eastern and southern boundaries. Its highest point is Mount Choqa (also known as Mount Birhan). According to the Central Statistical Agency of Ethiopia [8], this Zone has a total human population of 2,152,671 which $1,066,094$ are men and 1,086,577 are women. It covers an area of $14,004.47$ square kilometers with 213,568 or $9.92 \%$ are urban inhabitants. A total of 506,520 households were counted in this Zone, which results in an average of 4.25 persons per household. This Zone has seventeen districts and among these four dairy potential selected milk shed areas of eastern Gojjam Zone namely, Gozamin, Awabal, Dejen and Machakel districts were selected purposively based on the extent of dairy development interventions and distribution of dairy cattle for this study. Hence, many private smallholder farmers owning crossbred cows are found (Figure 1).

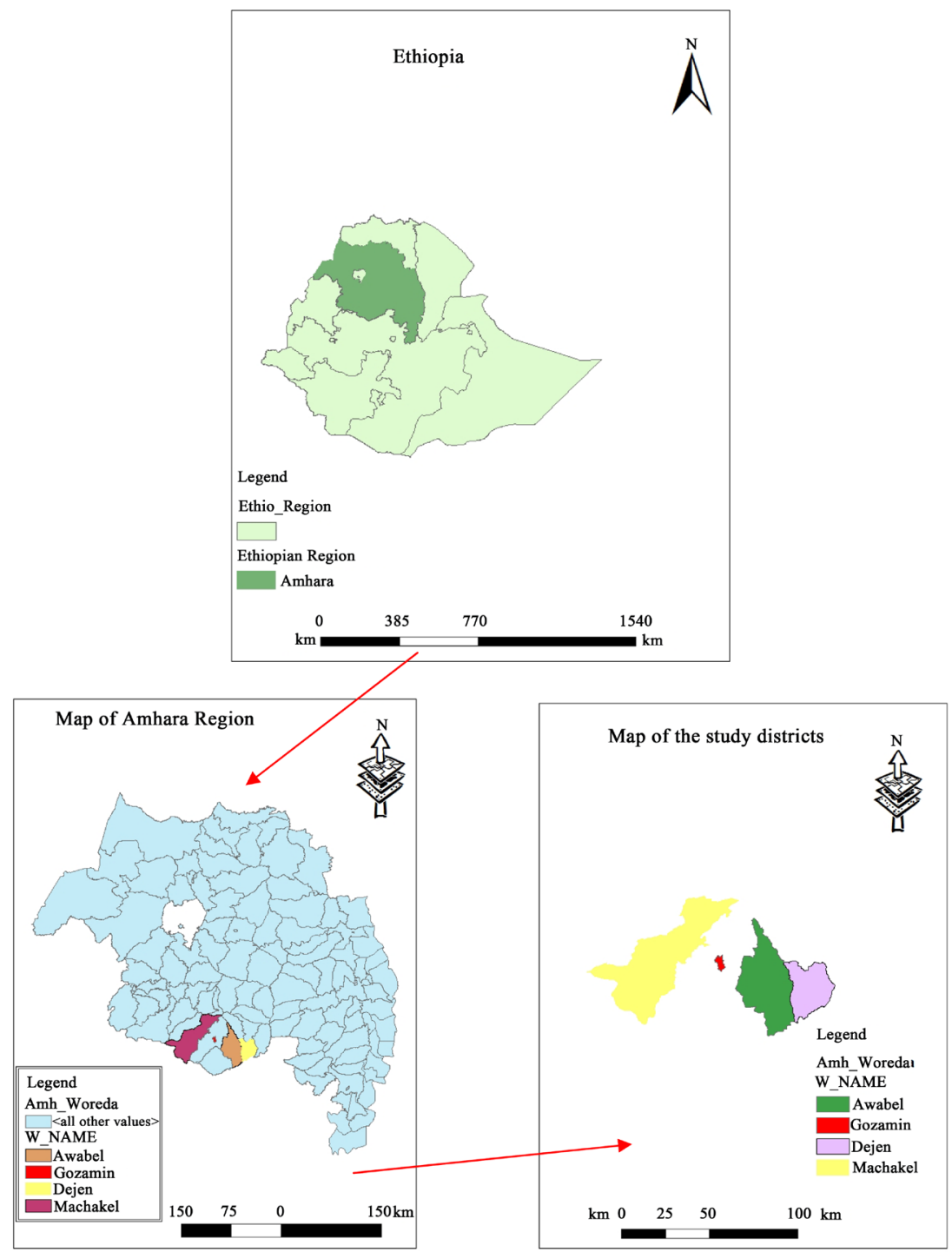

Figure 1 . The map of the study districts. 


\subsection{Study Design}

A cross-sectional type of study was carried out to assess, handling, processing and utilization, medicinal value and marketing activities as well as socio-economic benefits of cheese varieties under smallholder dairy production system in the study areas. A semi-structured survey questionnaire, farm inspection and secondary data sources were used to collect the required information.

\subsection{Data Collection and Sampling Techniques}

Data collection took place between July and November, 2016 with the help of enumerators recruited from each of the study sites. Two representatives peasant association (the smallest administrative unit in Ethiopia) were randomly selected in each of the four dairy potential of selected milkshed areas of eastern Gojjam. Sixty smallholder dairy producer farmers were selected using systemic random sampling techniques in each of the study sites. A total of 240 households were interviewed using semi structured to collect the required information. The questioner was used to generate information on the types of dairy products produced in the areas, production procedure, ingredients used, shelf life and medicinal uses of each product.

\subsection{Data Analysis}

After the completion of the data collection, the data were coded and entered into Statistical Package for Social Sciences (SPSS version 20) for analysis. The data were analyzed using quantitative and qualitative statistical procedures. The important statistical measures that were used to summarize and categorize the research data were means, percentages and standard errors.

\section{Results and Discussion}

\subsection{Consumption and Utilization Patterns of Traditional Cheese Varieties}

Table 1 shows consumption and utilization patterns of traditional cheese varieties. Majority of the respondents reported that Ayib (a traditional cottage cheese), $\mathrm{Me}$ tata (a traditional spiced blended fermented hard cottage cheese), Hazo (repeatedly exchange of old whey by fresh whey) and Zureshekefign are the common traditional cheese varieties produced and consumed in the study areas. All of the respondents in the areas reported that Ergo (naturally fermented sour milk) is used as a raw material for processing and production of different traditional dairy products and thus commonly consumed by the producers. The informants indicated that the major processed traditional cheese varieties in the study areas were Ayib followed by Metata, Hazo and Zureshekefign in respective order (Table 1). According to farmers' report processing of traditional cheese varieties such as Ayib, Metata, Hazo and Zureshekefign is a common processing practice of all smallholder farmers in the study areas. Even though all these traditional cheese varities reported are consumed, their relative level of consumption varied 
Table 1. Consumption and utilization patterns of traditional cheese varieties in the study districts $(n=240)$.

\begin{tabular}{|c|c|c|c|c|}
\hline \multirow{2}{*}{ Variables } & \multicolumn{4}{|c|}{ Respondents' response (\%) } \\
\hline & Awabal & Gozamin & Machakel & Dejen \\
\hline \multicolumn{5}{|l|}{ Process different varieties of cheese } \\
\hline Yes & $60(100)$ & $60(100)$ & $60(100)$ & $60(100)$ \\
\hline No & - & - & - & - \\
\hline \multicolumn{5}{|l|}{ Varieties of cheese } \\
\hline Ayib & $30(50.0)$ & $33(55.0)$ & $40(66.7)$ & $39(65.0)$ \\
\hline Metata & $18(30.0)$ & $15(25.0)$ & $13(21.7)$ & $11(18.3)$ \\
\hline Hazo & $9(15.0)$ & $8(13.3)$ & $5(8.3)$ & $7(11.7)$ \\
\hline Zureshekefign & $3(5.0)$ & $4(6.7)$ & $2(3.3)$ & $3(5.0)$ \\
\hline \multicolumn{5}{|l|}{ Majorly consume cheese varieties } \\
\hline Ayib & $41(68.3)$ & $30(50.0)$ & $32(53.3)$ & $50(83.3)$ \\
\hline Metata & $10(16.7)$ & $19(31.7)$ & $21(35.0)$ & $6(10.0)$ \\
\hline Hazo & $7(11.7)$ & $8(13.3)$ & $5(8.3)$ & $3(5.0)$ \\
\hline Zureshekefign & $2(3.3)$ & $3(5.0)$ & $2(3.3)$ & $1(1.7)$ \\
\hline \multicolumn{5}{|l|}{ Consumption of cheese varieties } \\
\hline Yes & $60(100)$ & $60(100)$ & $60(100)$ & $60(100)$ \\
\hline No & - & - & - & - \\
\hline \multicolumn{5}{|l|}{ Frequency of consumption } \\
\hline Everyday & - & - & - & - \\
\hline Once a week & $26(43.3)$ & $3(5.0)$ & $7(11.7)$ & $16(26.7)$ \\
\hline Three time a week & $12(20.0)$ & $9(15.0)$ & $13(21.7)$ & $17(28.3)$ \\
\hline During special occasion & $22(36.7)$ & $48.0(80.0)$ & $40(66.7)$ & $27(45.0)$ \\
\hline \multicolumn{5}{|l|}{ Who commonly consume? } \\
\hline Children & $33(55.0)$ & $38(63.3)$ & $38(63.3)$ & $48(80.0)$ \\
\hline Women & $15(25.0)$ & $15(25.0)$ & $18(30.0)$ & $8(13.3)$ \\
\hline Men & $12(20.0)$ & $7(11.7)$ & $4(6.7)$ & $4(6.7)$ \\
\hline \multicolumn{5}{|c|}{ Cheese varieties consumption with food items } \\
\hline Injera & $22(6.7)$ & $9(15.0)$ & $9(15.0)$ & $28(46.7)$ \\
\hline Mixed with wet & $4(6.7)$ & $4(6.7)$ & $4(6.5)$ & $7(11.7)$ \\
\hline Kita & $2(3.3)$ & $2(3.3)$ & $2(3.3)$ & $5(8.3)$ \\
\hline Mixed with vegetables & $3(5.0)$ & $14(23.3)$ & $14(23.3)$ & $7(11.7)$ \\
\hline Alone & $29(48.3)$ & $31(51.7)$ & $31(51.7)$ & $13(21.7)$ \\
\hline \multicolumn{5}{|c|}{ Constraints of cheese varieties consumption } \\
\hline Fasting days & $41(68.3)$ & $46(76.7)$ & $38(53.3)$ & $56(93.3)$ \\
\hline Seasonal demand and supply & $17(28.3)$ & $10(16.7)$ & $18(30.0)$ & $2(3.3)$ \\
\hline Spoilage & $2(3.3)$ & $4(6.7)$ & $4(6.7)$ & $2(3.3)$ \\
\hline
\end{tabular}

$\mathrm{n}=$ Total number of respondents interviewed; values in the table and the figures in parenthesis are represent frequencies with percentage. 
from household to household depending on the preference and shelf life. The high demand for processed Metata and Hazo cheese varieties in the areas suggests that there is a bright prospect for expanding and improving milk processing in the areas.

The respondents reported that traditional cheese varieties are consumed majorly by children, women and men as a side dish with different traditional food items such as Injera, Wet, Kita, vegetables and alone with various frequencies (Table 1). In some case especially during the holidays Metata cheese variety may also be added into the traditional cottage cheese and Metata cheese used for medicinal purpose is consumed by dissolving with clean tap water and fresh raw milk (Table 1). This probably increases the sensorial quality and intake. The present study is in agreement with [4], who reported that Ayib is consumed either spiced or natural as a side dish with different traditional food items, such as Kochikocha, salt and other herbs and spices, Markaa (Gonfo), Injera, Qincha, Dabbo and Anchotea. In the current study, fasting days and seasonal availability are the major constraints for the consumption of traditional cheese varieties. This indicated that the majority of farmers in the study areas are followers of Orthodox Christian faith and they are abstained from consuming dairy products during the main fasting season (Abiy Tsom/Hudade) and for over 200 days per annum. These constraints are the bottle neck for further development of the dairy sector. Therefore, under difficult conditions like these, processing of dairy products into Metata and selling in times of a greater seasonal demand during none fasting period is an option (Table 1). This study is in agreement with [9], who reported that market prices are influenced by season and fasting periods of the Ethiopian Orthodox Christian faith and the coping strategies for producers were focusing on milk processing and selling the processed products at times of higher prices.

\subsection{Spices Used in Metata Cheesemaking}

Table 2 shows spices used for making of Metata cheese by smallholder dairy producers in the study areas. In Ethiopia, most of smallholder dairy producers and substantial number of consumers do not have refrigerators and other modern preservation methods. It is, therefore, difficult to store milk and milk products for a long time [10]. The use of natural plant preservatives, therefore, considered an important and practical choice. Different plant spices are commonly used as additives in Ayib processing [9] [11]. According to [12], natural products such as spices can be appropriate alternatives to chemical preservatives used in various food industries minimizing their possible side effects and simultaneously improve the shelf life of food products.

All the respondents reported that twenty kinds of spices are used in the preparation of Metata cheese (Table 2). The present observation is in line with reports about spices used for Metata cheesemaking in Bahir Dar Zuria and Mecha districts in West Gojjam Zone, [10] and the types of spices used in the processing and storage of $A y i b$ in Shashemene area in Southern Ethiopia [11]. The effect of these plant spices on the quality and safety of Metata cheese deserves further study. 
Table 2. Spices used for making of Metata cheese in the study districts.

\begin{tabular}{ccc}
\hline Vernacular (Amharic) name & Common name & Scientific name \\
\hline Abish & Fenugreek & Trigonella foenum-graecum \\
Dimbillael & Coriande & Coriandrum sativum \\
Ird & Turmeric & Curcuma domestic \\
Krinfude & Clove & Syzygium aromaticum \\
Keyshinkurt & Shallot & Allium cepa \\
Korerima & Korerima & Aframomum Korerima \\
Kerefa & Cinnamon & Cinnamomum zeylanicum \\
Kundoberbere & Black pepper & Piper nigrum \\
Mekimeko & Mekimeko & Rumex abyssinicus \\
Nechishinkurt & Garlic & Allium sativum \\
Netch-azmud & Bishop's weed & Trachyspermum ammi \\
Berbere & Pepper & Capsicum annuum \\
Tirechew & Salt & Sodium chloride \\
Tikur-azmud & Black cumin & Nigella sativa \\
Tenadam & Rue & Ruta graveolence \\
Timiz & Binger & Piper longum \\
Senafitch & Thyme & Brassicanigra \\
Tosign & Mustard & Thymus serrulatus \\
Zekakibe (Basobila) & Ocimum basilium \\
Zingebile & Zingiber officinale \\
\hline
\end{tabular}

Source: (Current study, 2016).

\subsection{Purpose of the Spices Powder Used in Ayib Making}

The respondents reported that the major spices commonly used and its purpose in Ayib making in Awabal, Gozamin, Machakel and Dejen districts were Tena Adam (Rue), Nechishinkurt (Garlic), Dimbillael (Coriander) and Zingebile (Ginger), respectively (Table 3). Majority of the respondents reported that Tena Adam (Rue) is the most frequently used spices followed by Nechishinkurt (Garlic) and the other spices Dimbillael (Coriander) and Zingebile (Ginger) are seldom used in Ayib making depending on their availability (Table 2).

The present findings agree with [13], who reported that spices used in Ayib making in peri urban and urban areas of Dangila town of Amhara Regional State include Tena Adam (Rue) (100\%), Nechishinkurt (Garlic) (100\%), Zingebile (Ginger) (100\%) and Dimbillael (Coriander) (53.6\%). On the other hand, respondents in Awabal, Gozamin, Machakel and Dejen districts reported that the purpose of spices powder blended during Ayib and Metata cheesemaking increases shelf life followed by improved sensory taste, improved texture and for all purposes (increases shelf life, improved sensory taste and improved texture) (Table 3). These findings are in agreement with [14], who reported that consumer acceptability, texture and shelf life of Ayib samples were highly affected by the type and level of spice powder inclusion. 
Table 3. Major purpose of the spices powder used in Ayib making $(\mathrm{n}=240)$.

\begin{tabular}{ccccc}
\hline \multirow{2}{*}{ Variables } & \multicolumn{4}{c}{ Respondents' response (\%) } \\
\cline { 2 - 4 } & Awabal & Gozamin & Machakel & Dejen \\
\hline Types of spices & & & \\
Nechishinkurt (Garlic) & $16(26.7)$ & $19(31.7)$ & $19(31.7)$ & $37(61.7)$ \\
Zingebile (Ginger) & $3(5.0)$ & $3(5.0)$ & $3(5.0)$ & $8(13.3)$ \\
Ten Adam (Rue) & $36(60.0)$ & $34(56.7)$ & $34(56.7)$ & $9(15.0)$ \\
Dimbillael (Coriander) & $5(8.3)$ & $4(6.7)$ & $4(6.7)$ & $6(10.0)$ \\
Purpose of spices & & & & $30(50.0)$ \\
Improve sensory taste & $17(28.3)$ & $4(6.7)$ & $2(3.0)$ & $2(3.3)$ \\
Improve texture & $7(11.7)$ & $5(8.3)$ & $5(8.3)$ & $19(31.7)$ \\
Increases shelf life & $11(18.3)$ & $48(80.0)$ & $50(83.3)$ & $9(15.0)$ \\
\hline All purpose & $25(41.7)$ & $3(5.0)$ & $3(5.0)$ &
\end{tabular}

$\mathrm{n}=$ Total number of respondents interviewed; values in the table and the figures in parenthesis are represent frequencies with percentage.

\subsection{Metata Cheesemaking and Utilization}

Figures 2-4 show the flow chart of Metata cheesemaking in the study areas. Metata cheese is a widespread and unique traditional cheese variety made from Wegemit/Arera (defatted sour milk) in Awabal, Gozamin, and Machakel and Dejen districts. The processing protocol is Wegemit placed in a clay pot and heated on an open fire at approximately $45^{\circ} \mathrm{C}$ to $55^{\circ} \mathrm{C}$ until a distinct curd mass is formed within $30-40$ minutes and the vessel is removed from the fire and cooled to at room temperature. At the end of cooling, the curd and whey mixture is transferred into another smoked container and stored at room temperature. Subsequently, another fresh batch of $A y i b$ is produced following the same procedure and added into the previous batch after completely draining the whey from the earlier batch. This procedure continues every day for up to 4 to 10 days until ample quantity is attained for making Metata cheese.

While adequate quantity of curd $(5-6 \mathrm{~kg})$ is attained, the vessel containing the cured whey mixture is enclosed with clean luscious grass or leaves of Bisana (Croton macrostachyus), Abalo (Terminalia brownii) or Areg Eresa (unidentified). After that the vessel is tilted downward for continuous drainage of whey for up to 4 - 5 days during which the vessel cover is replaced each day. Following 5 days of whey drainage, twenty types of fine grounded spice powder are added into the vessel and mixed with the curd (Table 2). After adding these spices, the vessel is tilted down again for further drainage of whey for another 5 days with constant change of the vessel cover each day. The tilted vessel is then inverted and the drained curd mass is taken out from the vessel using spoon and mixed with twenty kinds of spices at one time (Table 2). These spices are blended in the form of fine powder and scrupulously mixed with the curd. 


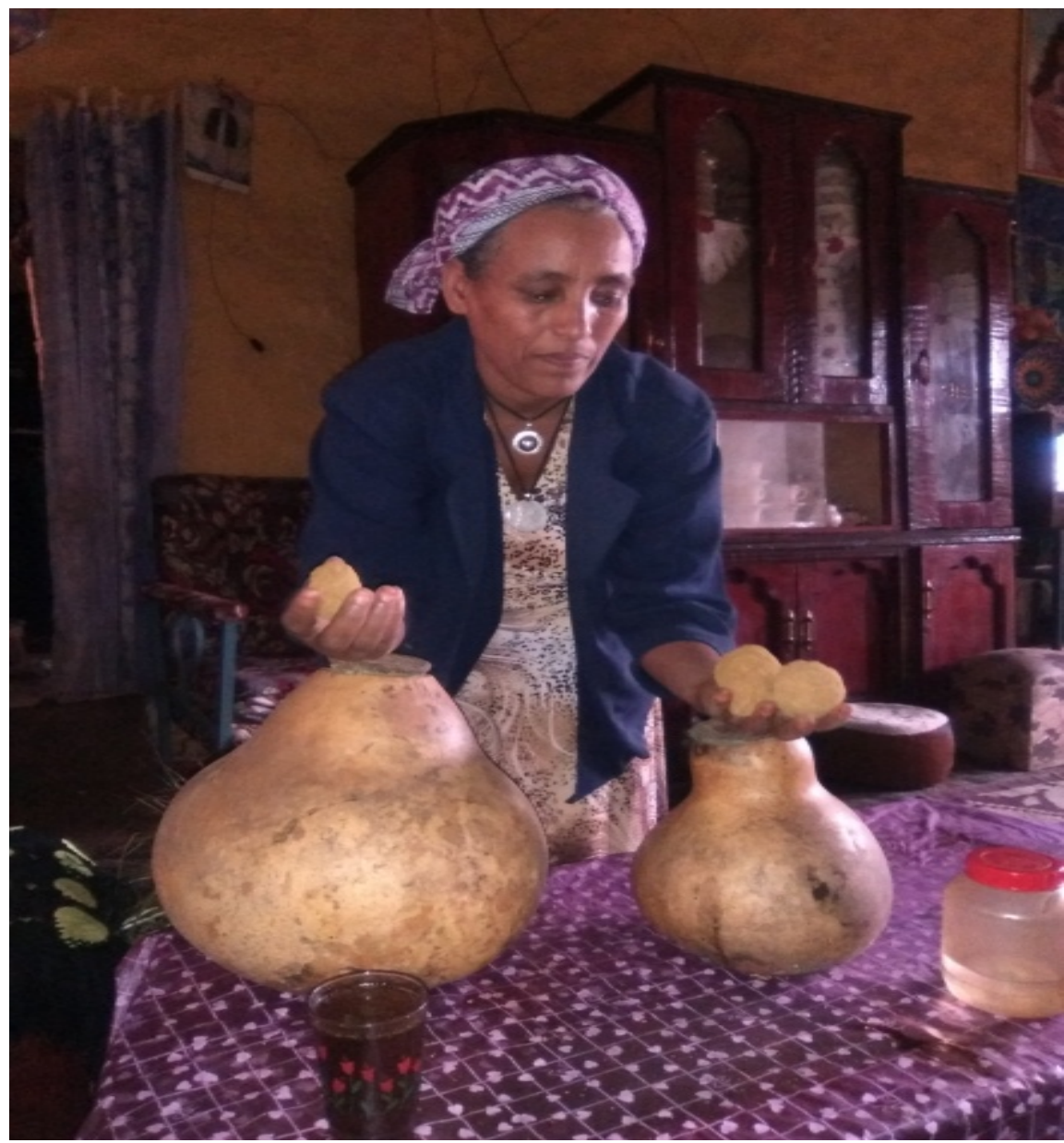

Figure 2. Photo of a thiry year Metata cheese.

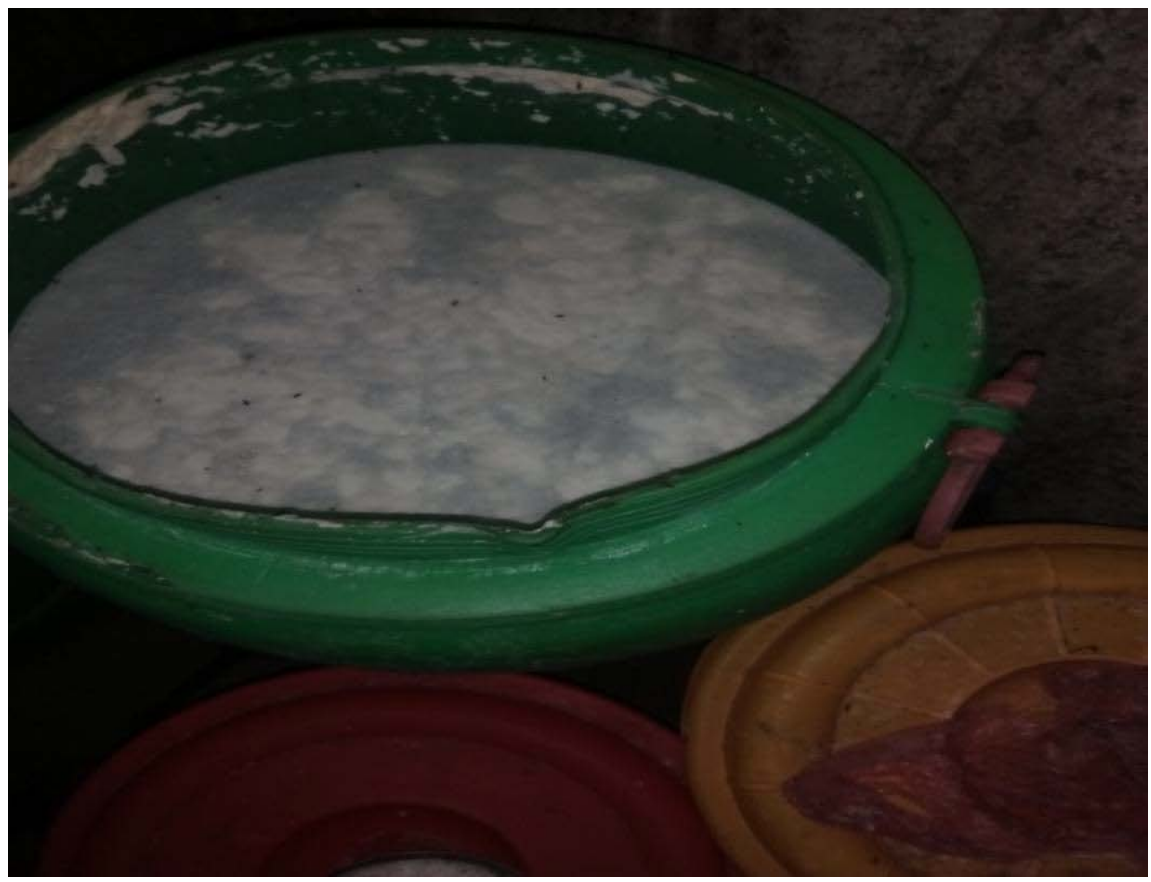

Figure 3. Photo of Hazo cheese. 


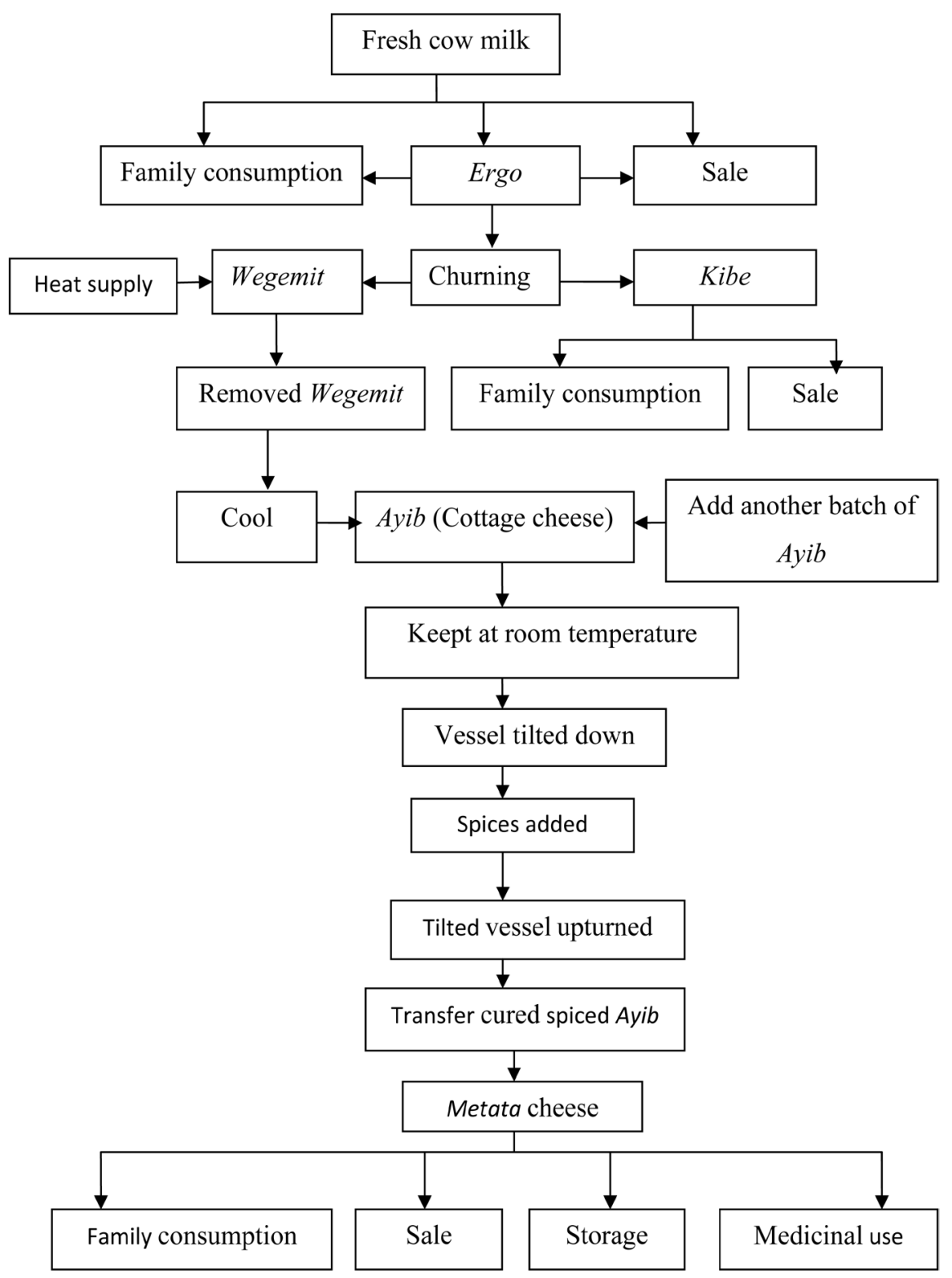

Figure 4. Flow diagram of Metata cheesemaking in the study areas.

Finally, the spiced curd is put into another smoked container and the vessel is enclosed with clean textile and kept at an ambient temperature for 20 - 25 days for natural fermentation to occur. All the respondents in the study areas reported that the vessel is unfastened before 25 days and this is the maximum time required for fermentation of Metata cheese. The fermentation process is accomplished in 25 days during which its colour changes from white to light green (blue mold) and Metata cheese is now prepared for home consumption, sale and further storage for either consumption or medicinal uses (Figure 2). The present finding is more or less in line with the study conducted by [13] and [10] in peri urban and urban areas of Dangila town and Bahir Dar Zuria and Mecha districts of western Gojjam, northwestern highlands of Ethiopia. 


\subsection{Ayib Making and Utilization}

Ayib is a traditional cottage cheese produced in Ethiopia. All of the respondents in the study areas reported that they make Ayib from cows' milk but do not make Ayib from small ruminants' milk mainly because of cultural taboos and availability. Wegemit/Arera (defatted sour milk), which is a by-product of the buttermaking process, is the raw material used for Ayib making. The Wegemit is placed in a clay pot and heated on slow fire at approximately $45^{\circ} \mathrm{C}$ to $55^{\circ} \mathrm{C}$ for about 30 minutes. After cooling, the whey is drained off (Figure 5). This protocol of Ayib making is in line with the reports of other authors in Ethiopia [4] [10] [13] [15] in the northwestern highlands of Amhara Region and in the central highlands of Ethiopia.

Ayib made at household level in the study areas are used for home consumption, making Hazo, Zureshekefign and Metata cheese varieties and marketed or sold (Figure 2, Figure 3 and Figure 5). The whey obtained is used for consumption by the family members and given to animals such as dogs, cats or calves. In the current study, on the average $10.1 \pm 0.17$ liters of Wegemit/ Arera is required to produce one kilogram of Ayib. This value is in line with the yield estimates for $A y i b$ reported by [16] and disagrees with [4], who reported that 8 liters of Arera is required to produce one kilogram of Ayib. The variation could be due to difference in the composition of the milk and the moisture content of the final product (Figure 5 and Figure 6).

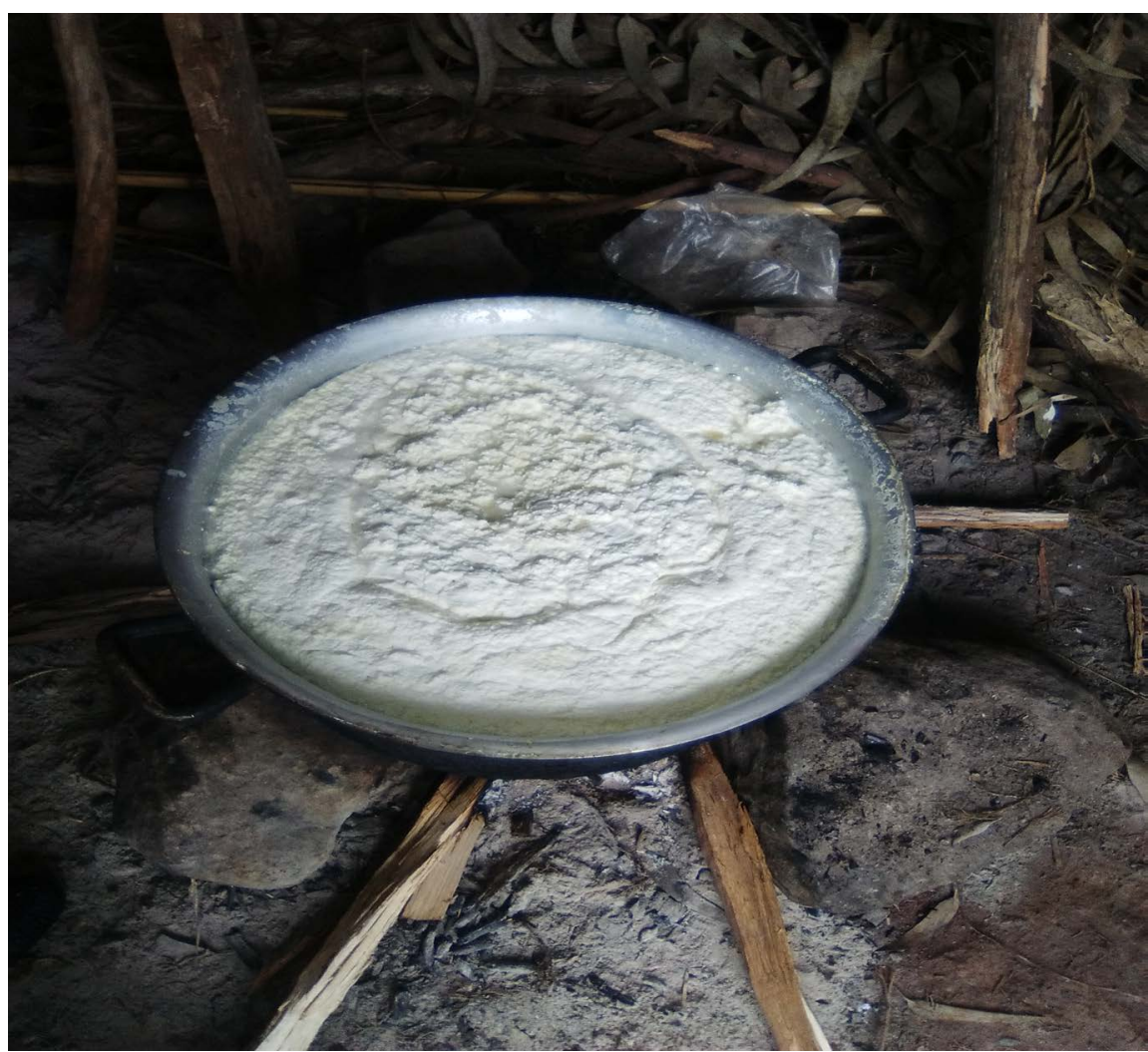

Figure 5. Photo of Ayib. 


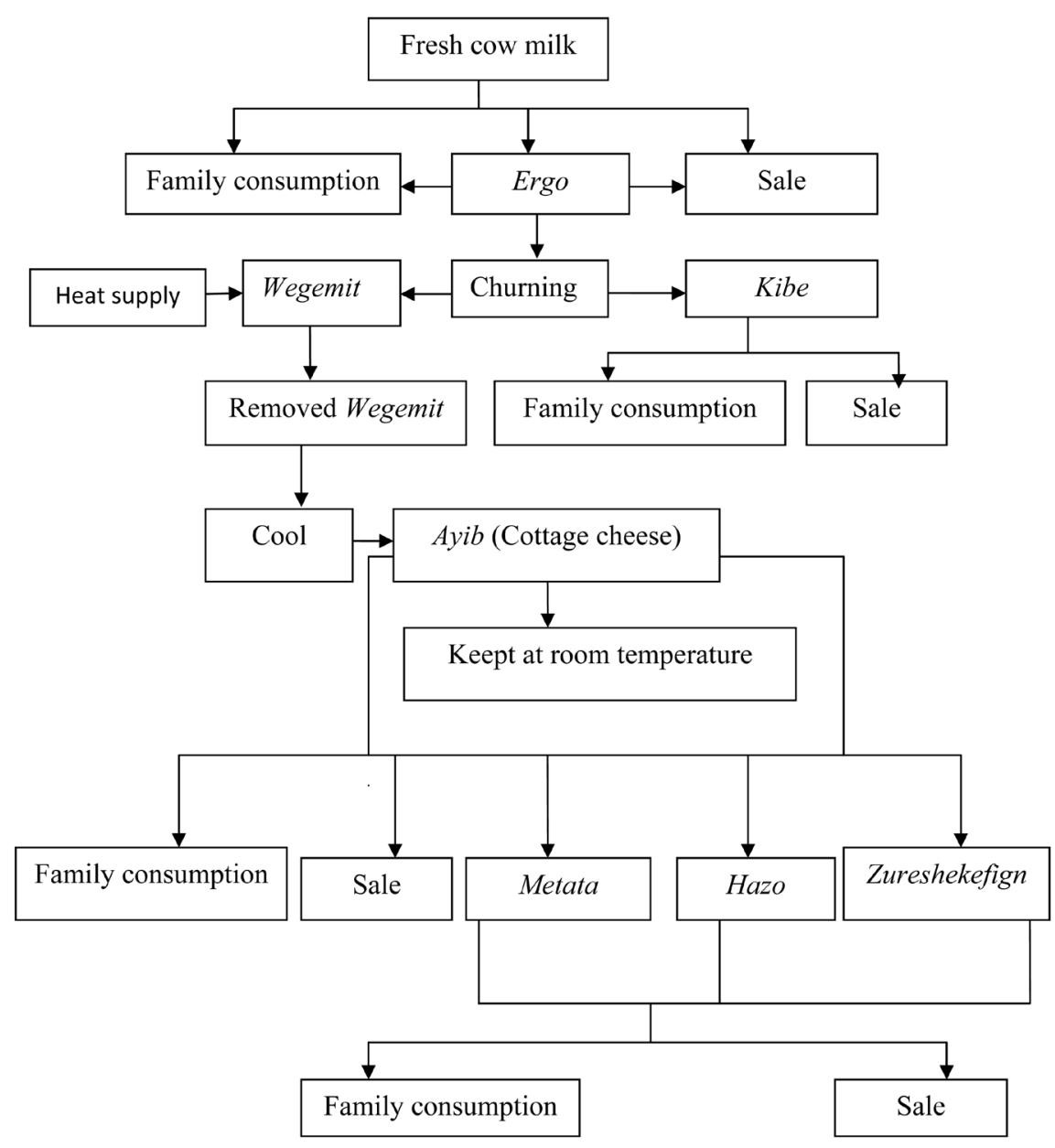

Figure 6. Flow diagram of Avib making in the study areas. Sources: (Current study, 2016).

\subsection{Containers Used for Processing and Storage of Traditional Cheese Varieties}

Table 4 shows the different containers used for storage of Ayib and Metata traditional cheese varieties produced in the study areas. Clay pot and Gourd ( $\mathrm{La}$ genaria siceraria) are the major containers used for storage of Ayib and Metata cheese followed by plastic containers. About 32\% - 49\% the respondents use gourd for storage of Metata cheese although some farmers use plastic containers and some uses both clay pot and plastic containers (Table 4). In general, the use of gourd, clay pot and plastic containers for storage of Ayib and Metata cheese types observed in the current study is in agreement with earlier report [10]; [13]; [15], which indicated that gourd (0\%), clay pot $(82.06 \%)$ and plastic $(17.94 \%)$ in Bahir Dar Zuria and Mecha districts and gourd (47.13\%), clay pot (27.63\%) and plastic containers (11.6\%) in Gondar and Dangila town of Amhara Regional state used for storage of Ayib and Metata cheese.

On the contrary the current study differs from the findings of [17], who reported that $91.6 \%$ of producers in Jimma towns use gourd for temporary storage of $A y i b$. The uses of various vessels in the different corners of the country could 
Table 4. Containers used for processing and storage of Ayib and Metata cheese $(\mathrm{n}=240)$.

\begin{tabular}{|c|c|c|c|c|c|c|c|c|}
\hline \multirow{3}{*}{$\begin{array}{c}\text { Containers } \\
\text { used for } \\
\text { storage }\end{array}$} & \multicolumn{8}{|c|}{ Respondents' response (\%) } \\
\hline & \multicolumn{2}{|c|}{ Awabal } & \multicolumn{2}{|c|}{ Gozamin } & \multicolumn{2}{|c|}{ Machakel } & \multicolumn{2}{|c|}{ Dejen } \\
\hline & Ayib & $M C$ & Ayib & $M C$ & Ayib & $M C$ & Ayib & $M C$ \\
\hline Clay pot & $39(65.0)$ & $14(23.3)$ & $21(35)$ & $13(21.7)$ & $31(56.7)$ & $12(20)$ & $48(80)$ & $5(8.3)$ \\
\hline Plastic & $18(30.0)$ & $6(10.0)$ & $22(36.7)$ & $10(16.7)$ & $16(26.7)$ & $9(15)$ & $8(13.3)$ & $3(5.0)$ \\
\hline $\begin{array}{l}\text { Clay pot } \\
\text { and plastic }\end{array}$ & $3(5.0)$ & $4(6.7)$ & $17(28.3)$ & $5(8.3)$ & $13(21.7)$ & $5(8.3)$ & $4(6.7)$ & $3(5.0)$ \\
\hline Gourd & - & $36(60.0)$ & - & $32(53.3)$ & - & $34(56.7)$ & - & $49(81.7)$ \\
\hline
\end{tabular}

$\mathrm{n}=$ Total number of respondents interviewed; $\mathrm{MC}=$ Metata cheese and values in the table and the figures in parenthesis are represent frequencies with percentage.

be the availability of materials and cultural differences as well as the purchasing power of modern utensils for storage of milk and milk products. The uses of different milk vessels and its effects on quality and safety of milk and milk products deserve further study.

\subsection{Shelf Life of Traditional Cheese Varieties}

Table 5 shows the shelf life of traditional cheese varieties in the study areas. All of the respondents in the study areas reported that Metata cheese variety has the longest shelf life followed by Hazo cheese variety (Table 5). The duration of storage years of Metata cheese without spoilage at an ambient temperature was reported to be $12.1 \pm 1.31,12.4 \pm 1.42,12.43 \pm 1.42$ and $12.1 \pm 1.31$ years at Awabal, Gozamin, Machakel and Dejen districts, respectively (Table 5). Thus, the long shelf life observed at household level could be attributed to the use of around twenty different locally available spices during preparation which leads to inhibition of the growth and multiplication of food spoilage microorganisms. In addition to this, good hygienic conditions followed during preparation at subsequent handling of Metata cheese could also possibly contribute to the long shelf life. The duration of storage Metata cheese reported in the present study is greater than the values reported by [9] and [10], who reported a shelf life of $2.8 \pm$ 1.2 years in the northwestern highlands of Ethiopia. The variation could be attributed to the type of spices used and knowledge gap among the households during preparation.

The average shelf life of Metata cheese used for consumption purpose in years were reported to be in Awabal and Dejen ( $3.1 \pm 0.32)$, in Gozamin (1.7 \pm 0.12$)$ and in Machakel $(3.0 \pm 0.43)$ and the medicinal use in years were in Awabal $(12.1 \pm 1.31)$, in Gozamin and Machakel (10.92 \pm 1.22$)$ and in Dejen (12.4 \pm 1.38). Whereas shelf life of Ayib and Hazo cheese during storage at ambient temperature was reported to be, $9.0 \pm 0.48-9.6 \pm 0.45$ and $18.15 \pm 0.36$ days, respectively. This study differs from the findings of [4] and [10], who reported that a short shelf life of $2-3$ days and $4.1 \pm 1.1$ days, for Ayib. This could be attributed mainly to uses of the spices Nechishinkurt (Garlic), Zingebile (Ginger), 
Table 5. Shelf life of traditional cheese varieties $(\mathrm{N}=240)$.

\begin{tabular}{|c|c|c|c|c|c|c|c|c|c|c|c|c|}
\hline \multirow{3}{*}{ Variables } & \multicolumn{12}{|c|}{ Response of respondents (Mean \pm SE) } \\
\hline & \multicolumn{3}{|c|}{ Awabal } & \multicolumn{3}{|c|}{ Gozamin } & \multicolumn{3}{|c|}{ Machakel } & \multicolumn{3}{|c|}{ Dejen } \\
\hline & Max & Min & Mean & Max & Min & Mean & Max & Min & Mean & Max & Min & Mean \\
\hline $\begin{array}{c}\text { SMC } \\
\text { (years) }\end{array}$ & 30 & 2 & $12.10 \pm 1.31$ & 40 & 2 & $12.40 \pm 1.42$ & 40 & 2 & $12.43 \pm 1.42$ & 30 & 2 & $12.1 \pm 1.31$ \\
\hline $\begin{array}{c}\text { MCC } \\
\text { (years) }\end{array}$ & 7 & 1 & $3.10 \pm 0.32$ & 4 & 1 & $1.70 \pm 0.12$ & 7 & 0.5 & $3.0 \pm 0.43$ & 7 & 1 & $3.01 \pm 0.32$ \\
\hline $\begin{array}{l}\text { MCMP } \\
\text { (years) }\end{array}$ & 30 & 2 & $12.10 \pm 1.31$ & 40 & 2 & $10.92 \pm 1.22$ & 40 & 2 & $10.92 \pm 1.22$ & 40 & 2 & $12.4 \pm 1.38$ \\
\hline $\begin{array}{c}\text { SA } \\
\text { (days) }\end{array}$ & 14 & 4 & $9.10 \pm 0.20$ & 14 & 4 & $9.30 \pm 0.47$ & 14 & 5 & $9.6 \pm 0.45$ & 14 & 4 & $9.0 \pm 0.48$ \\
\hline $\begin{array}{c}\text { SHC } \\
\text { (days) }\end{array}$ & 21 & 14 & $18.15 \pm 0.36$ & 21 & 14 & $18.15 \pm 0.36$ & 21 & 14 & $18.15 \pm 0.36$ & 21 & 14 & $18.17 \pm 0.35$ \\
\hline
\end{tabular}

SMC $=$ Shelf life of Metata cheese, $\mathrm{MCC}=$ Metata cheese used for consumption, MCMP $=$ Metata cheese used for medicinal purpose, $\mathrm{SA}=$ Shelf life of Ayib, SHC = Shelf life of Hazo cheese, $\mathrm{SE}=$ Standard error mean, $\mathrm{Mx}=$ maximum values, $\mathrm{Mn}=$ Minimum values and $\mathrm{n}=$ Total number of respondents interviewed.

Ten Adam (Rue) and Dimbillael (Coriander) in Ayib making and Hazo. [18], reported that spices have inherent antimicrobial substances that are widely used to extend shelf life and preserve foods for a long period of time.

The informant also mentioned that spoilage of dairy products during fasting and surplus milk production period is limited in the areas and they accredited this to the production of shelf stable products like Metata and Hazo cheese varieties. The longer shelf life of Metata and Hazo cheese varieties is important to smallholder farmers in the study areas who usually do not have milk preservation and cooling facilities.

\subsection{Therapeutic Uses of Metata Cheese}

Table 6 shows the therapeutic uses of Metata cheese. One peculiar characteristic of Metata cheese is its remedial value against a number of human illnesses. Majority of the respondents claim that Metata cheese is used to treat malaria and yellow fever (58.3\% to $70.0 \%$ ), increases appetite (6.7\% to $11.7 \%$ ), kill internal parasites of the gastro-intestinal tract (8.3\% to $11.7 \%)$, enhance digestion $(5.0 \%$ to $6.7 \%$ ) and avoid nausea (1.7\% to $3.3 \%$ ) (Table 6).

The present findings is in line with [10], who reported that Metata cheese is used to cure malaria and stomach upset in Bahir Dar Zuria and Mecha district western Gojjam. In addition to this [4], reported that fermented milk products used as a nutritional support to sick people, children and to pregnant and lactating mothers and served to respected guests. Thus, detailed scientific study is needed to investigate the healing values of Metata cheese in relation to the bioactive components, botanical preparation of the spices used as remedy to treat different diseases. 
Table 6. Therapeutic uses of Metata cheese based on sample households response ( $\mathrm{n}=$ 240).

\begin{tabular}{ccccc}
\hline \multirow{2}{*}{ Type of disease } & \multicolumn{4}{c}{ Respondents' response (\%) } \\
\cline { 2 - 5 } & Awabal & Gozamin & Machakel & Dejen \\
\hline Malaria and Yellow fever & $35(58.3)$ & $35(58.3)$ & $41(68.3)$ & $42(70.0)$ \\
Depressed appetite & $7(11.7)$ & $7(11.7)$ & $4(6.7)$ & $5(8.3)$ \\
Stomach upset (Ejeseb) & $4(6.7)$ & $4(6.7)$ & $3(5.0)$ & $4(6.7)$ \\
Metabolic disorder (bloating) & $2(3.3)$ & $2(3.3)$ & $2(3.3)$ & $2(3.3)$ \\
Gastro-intestinal parasite & $7(11.7)$ & $7(11.7)$ & $5(8.3)$ & $5(8.3)$ \\
Nausea & $1(1.7)$ & $2(3.3)$ & $2(3.3)$ & $2(3.3)$ \\
Digestion upset & $4(6.7)$ & $3(5.0)$ & $3(5.0)$ & - \\
\hline
\end{tabular}

$\mathrm{n}=$ Total number of respondents interviewed and values in the table and the figures in parenthesis are represent frequencies with percentage.

\subsection{Cleaning and Smoking Vessels Used for Storage of Milk and Milk Products}

Table 7 shows plants used for smoking, cleaning, water sources and frequency of cleaning of milk and milk products. All the respondents reported that they smoke and wash the utensils used for processing of milk and traditional cheese varieties. Majority of the respondents reported that the most extensive smoking plant species used for smoking milk and cheese varieties vessels in the study districts were Cheba (Acacia spp.) followed by Abalo (Terminalia brownii) and the other smoking plant species were occasionally used (Table 7). On the other hand, all the respondents reported that these plants are used to impart good aroma and flavor, increases the shelf life, facilitate fermentation and as well as for all uses (impart good aroma and flavour, increases shelf life and facilitate fermentation) to the milk and cheese varieties (Table 7). [19], who reported that use of smoked containers for souring may help produce a relatively more wholesome fermented product with a better taste and keeping quality. Thus, the effect of these plant species on the quality and safety of milk and traditional cheese varieties deserve for further study.

The present findings are consistent with the findings of [10], [13] and [15], who reported similar practices in Gondar town, urban and peri urban areas of Dangila town and Bahir Dar Zuria and Mecha districts of western Gojjam of the Amhara Regional State, respectively. Moreover, the respondents reported that the milk vessels are washed with Dama Kessie (Ocimum hardiense) followed by Bisana leaf (Croton macrostachyus) with cold water alone and cold water with soap with washing frequency of once a day using water from boreholes (Table 7). This report is in agreement with the findings of [13], reported that the most common plant leaves used for washing milk vessels were bsana (Croton macrostachyus), nacha and Cheba (Acacia spp.) in peri-urban and urban areas of Dangila town. 
Table 7. Plants used for smoking, cleaning, water sources and frequency of cleaning milk and traditional cheese varieties utensils $(n=240)$.

\begin{tabular}{|c|c|c|c|c|}
\hline \multirow{2}{*}{ Variables } & \multicolumn{4}{|c|}{ Respondents' response (\%) } \\
\hline & Awabal & Gozamin & Machakel & Dejen \\
\hline \multicolumn{5}{|l|}{ Do you smoke vessels? } \\
\hline Yes & $60(100)$ & $60(100)$ & $60(100)$ & $60(100)$ \\
\hline No & - & - & - & - \\
\hline \multicolumn{5}{|l|}{ Plants used for smoking milk vessels } \\
\hline Woira (Olea africana) & $3(5.0)$ & $2(3.3)$ & $2(3.3)$ & $2(3.3)$ \\
\hline Tsid (Juniperus procera L.) & $3(5.0)$ & $2(3.3)$ & $2(3.3)$ & $2(3.3)$ \\
\hline Cheba (Acacia spp.) & $32(53.3)$ & $32(53.3)$ & $41(68.3)$ & $43(71.7)$ \\
\hline Abalo (Terminalia brownii) & $13(21.7)$ & $11(23.3)$ & $8(13.3)$ & $6(10.0)$ \\
\hline Kega (Rose Abyssinia) & $3(5.0)$ & $3(5.0)$ & $2(3.3)$ & $1(1.7)$ \\
\hline Dokima (Syzygiumguineense) & $1(1.7)$ & $2(3.3)$ & $1(1.7)$ & $1(1.7)$ \\
\hline Embuay (Solanum incanum) & $2(3.3)$ & $3(5.0)$ & $1(1.7)$ & $2(3.3)$ \\
\hline Maize cobe (Zea Mays) & $2(3.3)$ & $3(5.0)$ & $2(3.3)$ & $2(3.3)$ \\
\hline Kitkita (Dodonaea angustifolia) & $1(1.7)$ & $2(3.3)$ & $1(1.7)$ & $1(1.7)$ \\
\hline \multicolumn{5}{|l|}{ Purpose of smoking } \\
\hline Impart good aroma and flavor & $37(61.7)$ & $41(68.3)$ & $34(56.7)$ & $47(78.3)$ \\
\hline Increase shelf life & $16(26.7)$ & $14(23.3)$ & $15(25.0)$ & $8(13.3)$ \\
\hline Facilitate fermentation & $5(8.3)$ & $2(3.3)$ & $7(11.7)$ & $3(5.0)$ \\
\hline All uses & $2(3.3)$ & $3(5.0)$ & $4(6.7)$ & $2(3.3)$ \\
\hline \multicolumn{5}{|l|}{ Plants leaves used for cleaning } \\
\hline Bisana (Croton macrostachyus) & $18(30.0)$ & $3(5.0)$ & $12(20.0)$ & $2(3.3)$ \\
\hline Necha (unidentified) & $5(8.3)$ & $4(6.7)$ & $9(15.0)$ & $5(8.3)$ \\
\hline Dama kessie (Ocimum hardiense) & $25(41.7)$ & $37(61.7)$ & $30(50.0)$ & $41(68.3)$ \\
\hline Tena Adam (Rue) & $7(11.7)$ & $10(16.7)$ & $1(1.7)$ & $5(8.3)$ \\
\hline Teje Sar (unidentified) & $4(6.7)$ & $4(6.7)$ & $5(8.3)$ & $3(5.0)$ \\
\hline Kacha (unidentified) & $1(1.7)$ & $2(3.3)$ & $3(5.0)$ & $4(6.7)$ \\
\hline \multicolumn{5}{|l|}{ Do you wash all milking vessels? } \\
\hline Yes & $60(100)$ & $60(100)$ & $60(100)$ & $60(100)$ \\
\hline No & - & - & - & - \\
\hline \multicolumn{5}{|l|}{ Water sources used for cleaning } \\
\hline Tap & $40(66.7)$ & $18(30.0)$ & $8(13.3)$ & $8(13.3)$ \\
\hline River & $6(10.0)$ & $6(10.0)$ & $13(21.7)$ & $14(23.3)$ \\
\hline Borehole & $11(18.3)$ & $19(31.7)$ & $22(36.7)$ & $35(58.3)$ \\
\hline Spring & $1(1.7)$ & $15(25.0)$ & $15(25.0)$ & $1(1.7)$ \\
\hline All water sources & $2(3.3)$ & $2(3.3)$ & $2(3.3)$ & $2(3.3)$ \\
\hline \multicolumn{5}{|l|}{ Type of water used for washing } \\
\hline Hot water & $4(6.7)$ & $20(33.3)$ & $1(1.7)$ & $4(6.7)$ \\
\hline Hot water with soap & $2(3.3)$ & $5(8.3)$ & $1(1.7)$ & $3(5.0)$ \\
\hline Cold water & $36(60.0)$ & $31(51.7)$ & $48(80.0)$ & $40(66.7)$ \\
\hline Cold water with soap & $18(30.0)$ & $4(6.7)$ & $10(16.7)$ & $13(21.7)$ \\
\hline \multicolumn{5}{|l|}{ Frequency of washing milking vessels } \\
\hline Always after uses & $3(5.0)$ & $3(5.0)$ & $8(13.3)$ & $2(3.3)$ \\
\hline Once a day & $37(61.7)$ & $25(41.7))$ & $24(40.0)$ & $44(73.3)$ \\
\hline Twice a day & $18(30.0)$ & $29(48.3))$ & $26(43.3)$ & $12(20.0)$ \\
\hline Three times a day & $2(3.3)$ & $3(5.0)$ & $2(3.3)$ & $2(3.3)$ \\
\hline
\end{tabular}

$\mathrm{n}=$ Total number of respondents interviewed and values in the table and the figures in parenthesis are represent frequencies with percentage. 


\subsection{Marketing Activities of Traditional Cheese Varieties}

Table 8 shows marketing activities of traditional cheese varieties in Awabal, Gozamin, Machakel and Dejen districts. In the present study majority of the respondents use an informal marketing system to sell the traditional cheese varieties to neighbours, local dairy product shops, individual consumers, hotel and restaurant and local markets. In addition, the smallholder dairy producer in Awabal, Machakel, Gozamin and Dejen districts sell the traditional cheese varieties through farmers marketing channel. Like in most parts of the Ethiopian highlands, mainly raw milk, butter and ghee were marketed by the primary dairy producers. Furthermore, 78\%, 91.1\%, 55.5\% and 50.0\% of the respondents of Awabal, Gozamin, Machakel, and Dejen district smallholder dairy producers were selling cheese varieties and the remaining $21.7 \%, 8.3 \%, 45.0 \%$, and $50.0 \%$ of the respondents not sold due to traditional taboos, unable to sell in an open market in all districts.

The respondents reported that major quality factors affecting the prices of traditional cheese varieties were freshness, aroma and flavour and cleans followed by amount of whey and colour (Table 8). The present study is in agreement with the report of [9], [13] and [15] in the north-western highlands of Ethiopian region, where most of the farmers sold cheese varieties. Majority of the respondents sold cheese varieties with different selling price in the study districts during none fasting and fasting days with $100 \%$ cash means of payment (Table 8). As it is common in Ethiopia, informal dairy marketing is the sole marketing system in the study districts; these involved direct delivery of $A y i b$, Hazo and Metata cheese varieties by producers to individual consumers, hotel and restaurant in the immediate neighbourhood and sales to itinerant traders and individuals in nearby areas.

The prices of Ayib, Hazo and Metata traditional cheese varieties from the point of production to the next outlets were determined by the producers and get major sources of market information from extension agent followed by personal visit based on the accessibility and reliability. 78.3\% in Awabal, $81.7 \%$ in Gozamin, $76.7 \%$ in Machakel and $86.7 \%$ in Dejen districts of the farmers were transported the traditional cheese varieties by public transportation followed on foot and cart. At all in the study districts dairy producers were not used private car for transport of dairy products to market outlets. The largest primary sale outlets for producers in the study areas consists of direct sales of traditional cheese varieties by producers to consumers, typically through farmer delivery to nearby, hotel and restaurant. The second most important players in the informal markets were dairy product shops. Similar findings were reported by [9] in western highlands of Ethiopia.

\subsection{Socio-Economic Benefit and Marketing Constraints of Traditional Cheese Varieties}

Table 9 shows important uses of socio-economic aspects income generated from sales of traditional cheese varieties and marketing constraints. The majority of 
Table 8. Marketing activities of traditional cheese varieties in the study districts $(\mathrm{n}=$ 240).

\begin{tabular}{|c|c|c|c|c|}
\hline \multirow{2}{*}{ Variables } & \multicolumn{4}{|c|}{ Respondents' response (\%) } \\
\hline & Awabal & Gozamin & Machakel & Dejen \\
\hline \multicolumn{5}{|c|}{ Do you sell cheese varieties? } \\
\hline Yes & $47(78.3)$ & $55(91.7)$ & $33(55.0)$ & $30(50.0)$ \\
\hline No & $13(21.7)$ & $5(8.3)$ & $27(45.0)$ & $30(50.0)$ \\
\hline \multicolumn{5}{|l|}{ Quality parameter } \\
\hline Color & $21(35.0)$ & $1(1.7)$ & $9(15.0)$ & $10(16.7)$ \\
\hline Amount of whey & $4(6.7)$ & $4(6.7)$ & $8(13.3)$ & $6(10.0)$ \\
\hline Freshness & $18(30.0)$ & $35(58.3)$ & $22(36.7)$ & $25(41.7)$ \\
\hline Aroma and flavor & $12(20.0)$ & $9(15.0)$ & $11(18.3)$ & $12(20.0)$ \\
\hline Cleanness & $4(6.7)$ & $8(13.3)$ & $7(11.7)$ & $5(8.3)$ \\
\hline All & $1(1.7)$ & $3(5.0)$ & $3(5.0)$ & $2(3.3)$ \\
\hline \multicolumn{5}{|c|}{ Sources of market information } \\
\hline Extension agent & $44(73.3)$ & $46(76.7)$ & $41(68.3)$ & $39(65.0)$ \\
\hline Mass media & - & - & - & - \\
\hline Neighbours & $5(8.3)$ & $4(6.7)$ & $3(5.0)$ & $1(1.7)$ \\
\hline Personal visit & $10(16.7)$ & $8(13.3)$ & $13(21.7)$ & $18(30.0)$ \\
\hline Traders & $1(1.7)$ & $2(3.3)$ & $3(5.0)$ & $2(3.3)$ \\
\hline NGO & - & - & - & - \\
\hline \multicolumn{5}{|c|}{ Selection of market information } \\
\hline Accessibility & $37(61.7)$ & $50(83.3)$ & $51(85.0)$ & $53(88.3)$ \\
\hline Reliability & $11(18.3)$ & $6(10.0)$ & $7(11.7)$ & $3(5.0)$ \\
\hline Both & $12(20.0)$ & $4(6.7)$ & $2(3.3)$ & $4(6.7)$ \\
\hline \multicolumn{5}{|l|}{ Ayib price per kg (Birr) } \\
\hline None fasting period & $8.75 \pm 0.61$ & $9.53 \pm 0.17$ & $8.63 \pm 0.13$ & $8.70 \pm 0.23$ \\
\hline Fasting period & $4.96 \pm 0.35$ & $6.13 \pm 0.13$ & $5.20 \pm 0.94$ & $5.27 \pm 0.17$ \\
\hline \multicolumn{5}{|l|}{ Hazo price per kg (Birr) } \\
\hline None fasting period & $10.28 \pm 0.05$ & $9.46 \pm 0.55$ & $8.80 \pm 0.58$ & $11.56 \pm 0.25$ \\
\hline Fasting period & $5.50 \pm 0.25$ & $6.25 \pm 0.60$ & $5.50 \pm 0.50$ & $4.99 \pm 0.25$ \\
\hline \multicolumn{5}{|l|}{ Metata price per kg (Birr) } \\
\hline None fasting period & $40.25 \pm 0.25$ & $39.65 \pm 0.25$ & $42.55 \pm 0.50$ & $41.25 \pm 0.70$ \\
\hline Fasting period & $22.50 \pm 0.30$ & $20.50 \pm 0.25$ & $21.80 \pm 0.75$ & $20.50 \pm 0.65$ \\
\hline \multicolumn{5}{|l|}{ Mode of payment } \\
\hline Cash & $60(100)$ & $60(100)$ & $60(100)$ & $60(100)$ \\
\hline Advance & - & - & - & - \\
\hline Credit & - & - & - & - \\
\hline
\end{tabular}




\section{Continued}

\begin{tabular}{|c|c|c|c|c|}
\hline Buyer type & & & & \\
\hline Individual consumer & $14(23.3)$ & $21(35.0)$ & $23(38.3)$ & $18(30.0)$ \\
\hline Hotel and restaurant & $32(53.3)$ & $35(58.3)$ & $32(53.3)$ & $36(60.0)$ \\
\hline Traders & $14(23.4)$ & $4(7.3)$ & $5(8.3)$ & $6(10.0)$ \\
\hline Cooperatives & - & - & - & - \\
\hline \multicolumn{5}{|l|}{ Sales outlets } \\
\hline Farm gate & $8(13.3)$ & $9(15.0)$ & $8(13.3)$ & $5(8.3)$ \\
\hline Deliver to buyer & $40(66.7)$ & $41(68.3)$ & $42(70.0)$ & $47(78.3)$ \\
\hline Shops & $12(20.0)$ & $10(16.7)$ & $10(16.7)$ & $8(13.3)$ \\
\hline \multicolumn{5}{|c|}{ Reason for choice of sales outlets } \\
\hline Price & $3(5.0)$ & $2(3.3)$ & $3(5.0)$ & $2(3.3)$ \\
\hline Distance & $7(11.7)$ & $5(8.3)$ & $3(5.0)$ & $3(5.0)$ \\
\hline Reliable customer & $50(83.3)$ & $53(88.3)$ & $54(90.0)$ & $55(91.7)$ \\
\hline \multicolumn{5}{|l|}{ Mode of transport } \\
\hline Cart & $3(5.0)$ & $4(6.7)$ & - & $2(3.3)$ \\
\hline Private car & - & - & - & - \\
\hline Public transportation & $47(78.3)$ & $49(81.7)$ & $46(76.7)$ & $52(86.7)$ \\
\hline On foot & $10(16.7)$ & $7(11.7)$ & $14(23.3)$ & $6(10.0)$ \\
\hline
\end{tabular}

$\mathrm{n}=$ Total number of respondents interviewed and values in the table and the figures in parenthesis are represent frequencies with percentage.

Table 9. Socio-economic benefit and marketing constraints of cheese varieties $(n=240)$.

\begin{tabular}{ccccc}
\hline \multirow{2}{*}{ Variables } & \multicolumn{3}{c}{ Respondents' response (\%) } \\
\cline { 2 - 4 } $\begin{array}{c}\text { Socio-economic benefit } \\
\text { To get additional income }\end{array}$ & Awabal & Gozamin & Machakel & Dejen \\
For children school fee & $8(13.3)$ & $21(35.0)$ & $13(21.7)$ & $6(10.0)$ \\
To fulfill household necessities & $40(66.7)$ & $29(48.3)$ & $41(68.3)$ & $49(81.7)$ \\
To purchase of dairy inputs & $12(20.0)$ & $3(5.0)$ & $6(10.0)$ & $5(8.3)$ \\
$\quad$ Constraints & & & & \\
Transportation access & $2(3.3)$ & $1(1.7)$ & $2(3.3)$ & $3(5.0)$ \\
Quality deterioration & $3(5.0)$ & $3(5.0)$ & $1(1.7)$ & $2(3.3)$ \\
Absence of sufficient buyer & $36(60.0)$ & $18(30.0)$ & $38(63.3)$ & $40(66.7)$ \\
Distance to the market & $2(3.3)$ & $4(6.7)$ & $2(3.3)$ & $2(3.3)$ \\
Traditional taboos & $7(11.7)$ & $24(40.0)$ & $11(18.3)$ & $7(11.7)$ \\
Seasonal supply & $10(16.7)$ & $10(16.7)$ & $6(10.0)$ & $6(10.0)$ \\
\hline
\end{tabular}

$\mathrm{n}=$ Total number of respondents interviewed and values in the table and the figures in parenthesis are represent frequencies with percentage. 
the respondents reported that the socio-economic contribution of selling traditional cheese varieties, $66.7 \%, 48.3 \%, 68.3 \%$ and $81.7 \%$ of the respondents in Awabal, Gozamin, Machakel and Dejen districts were used for to fulfill house hold necessities; the reaming used to purchase of dairy inputs, sources of additional income and fulfill children school fee in the respective order (Table 9). This indicated that income generated from traditional cheese varieties is small enough to purchase dairy inputs, additional income and children school fee. Therefore dairy farmers use income generated from traditional cheese varieties for fulfill immediate household necessities. The current study is in agreement with [20], reported that $49 \%$ to $38.6 \%$ dairy income is pay for health care and to purchase soap and clothes for fulfill household necessities in Wolaita zone, southern Ethiopia region.

The respondents reported that the major marketing constraints of traditional cheese varieties in the study districts were absences of sufficient buyer in the traditional cheese marketing outlets' and followed by traditional taboos, season (fasting and surplus), distance to the market, quality deterioration and transportation accesses in respective of their order (Table 9). The current findings in line with [9] [10] [13] [15] [21], who reported that the major constraints affecting marketing activities of dairy products were season, fasting and none fasting days, cultural taboos, distances to urban sites and the quality and sources of dairy products in the Ezha district of the Gurage Zone, Southern Ethiopia and northwestern highlands of Ethiopia.

\section{Conclusion}

Ayib, Metata, Hazo and Zureshekefign traditional cheese varieties are a common processing practice of all smallholder farmers in the study areas. These traditional cheese varieties are produced and highly demanded by the consumer in the study areas. The high demand for these long shelf life processed traditional cheese varieties in the areas suggests that there is a bright prospect for expanding and improving milk processing. Therefore, it could be concluded that the spoilage of dairy products during fasting and surplus milk production period is limited in the areas and they are accredited to the production of shelf stable products like Metata and Hazo cheese varieties. Thus, further scientific investigation is also needed to confirm the claimed nutritional and medicinal values of these traditional cheese varieties in order to improve and scale up its production to a commercial level.

\section{Acknowledgements}

The authors are grateful to Adigrat University, Ethiopian Institute of Agricultural Research and Ministry of Education of the Federal Democratic Republic of Ethiopia for funding the research work; Haramaya University, dairy farmers of Dejen, Gozamin, Awabal, Machakel districts and East Gojjam Zonal Office of Livestock Resource and Fisheries for providing all necessary information/facilities during the course of the study. 


\section{Conflict of Interest}

We certify that there is no conflict of interest with any financial organization regarding the material discussed in the manuscript.

\section{References}

[1] Ashenafi, M. (2006) A Review on the Microbiology of Indigenous Fermented Foods and Beverages of Ethiopia. Ethiopian Journal of Biological Science, 5, 189-245.

[2] Abegaz, K. (2000) Isolation, Characterization and Identification Lactic Acid Bacteria Involved in Traditional Fermentation of Borde, an Ethiopian Cereal Beverage. African Journal of Biotechnology, 6, 1469-1478.

[3] Chelule, P.K., Mokoena, M.P. and Gqaleni, N. (2010) Advantages of Traditional Lactic Acid Bacteria Fermentation of Food in Africa. Current Research, Technology and Education Topics in Applied Microbiology and Microbial Biotechnology, 13, 169-173.

[4] Gonfa A., Foster, H.A. and Holzapfel, W.H. (2001) Field Survey and Literature Review on Traditional Fermented Milk Products of Ethiopia. International Journal of Food Microbiology, 68, 173-186. https://doi.org/10.1016/S0168-1605(01)00492-5

[5] Assefa, E., Beyene, F. and Santhanam, A. (2008) Isolation and Characterization of Inhibitory Substance Producing Lactic Acid Bacteria from Ergo, Ethiopian Traditional Fermented Milk. Livestock Research for Rural Development, 20, 1-5.

[6] Geremew, T., Kebede, A. and Andualem, B. (2015) The Role of Spices and Lactic Acid Bacteria as Antimicrobial Agent Extends the Shelf Life of Metata Ayib (Traditional Ethiopian Spiced Fermented Cottage Cheese). Journal of Food Science and Technology, 52, 5661-5670. https://doi.org/10.1007/s13197-014-1694-y

[7] Yilma, Z. and Faye, B. (2006) Handling and Microbial Load of Cow's Milk and Ergo Fermented Milk Collected from Different Shops and Producers in Central Highlands of Ethiopia. Ethiopian Journal of Animal Production, 6, 67-82.

[8] Central Statistical Authority (CSA) (2007) Summary and Statistical Report of Population and Housing Census. Federal Democratic Republic of Ethiopia Population and Census Commission.

[9] Alemayehu, Y., Wurzinger, M., Tegegne, A. and Zollitsch, W. (2009) Handling, Processing and Marketing of Milk in the Northwestern Ethiopian Highlands. $\mathrm{Li}$ vestock Research for Rural Development, 21, 7.

[10] Seifu, E. and Tassew, A. (2014) Small-Scale Milk Processing, Utilization and Marketing of Traditional Dairy Products in Bahir Dar Zuria and Mecha Districts, Northwestern Ethiopia. Journal of Food Technology Research, 1, 122-132. https://doi.org/10.18488/journal.58/2014.1.2/58.2.122.132

[11] Kassa, B. (2008) Cottage Cheese Production in Shashemene and the Role of Rue (Ruta Chalepensis) and Garlic (Allium Sativum) on Its Quality and Shelf Life. MSc. Thesis, School of Graduate Studies of Hawassa University, $126 \mathrm{p}$.

[12] Mishra, N. and Behal, K.K. (2010) Antimicrobial Activity of Some Spices against Selected Microbes. International Journal of Pharmacy and Pharmacology Science, 2 , 187-196.

[13] Aysheshim, B., Beyene, F. and Eshetu, M. (2015) Handling, Processing and Marketing of Cow Milk in Urban and Peri Urban Area of Dangila Town, Western Amhara Region, Ethiopia. Global Journal of Food Science and Technology, 3, 159-174.

[14] Regu, M., Yilma, Z. and Seifu, E. (2016) Effect of Garlic (Allium sativum) and Gin- 
ger (Zingiber officinale) Powder on Chemical Composition and Sensory Property of Ayib Ethiopian Cottage Cheese. International Food Research Journal, 23, 1226-1232.

[15] Shewangizaw, A., Ahmed, M. and Nunu, H. (2016) Handling, Processing and Utilization of Milk and Its Products in Gondar Town, Ethiopia. Journal of Life Science and Biomedicine, 6, 120-126.

[16] Yilma, Z. and Inger, L. (2001) Milk Production, Processing, Marketing and The Role of Milk and Milk Products on Smallholder Farmers' Income in the Central Highlands of Ethiopia. Proceedings of the 8 th Annual Conference of the Ethiopian Society of Animal Production, Addis Ababa, 24-26 August 2000, 139-154.

[17] Solomon, T. and Ketema, T. (2011) Microbiological Safety of Street Vended Ayib in Jimma Town, Southwest Ethiopia. Ethiopian Journal of Educational and Science, 7 , 81-91.

[18] Seifu, E. (2013) Chemical Composition and Microbiological Quality of Metata Ayib: A Traditional Ethiopian Fermented Cottage Cheese. International Food Research Journal, 20, 93-97.

[19] Ashenafi, M. (1996) Effect of Container Smoking and Incubation Temperature on the Microbiological and Some Biochemical Qualities of Fermenting Ergo, Traditional Ethiopian Sour Milk. International Dairy Journal, 6, 95-104.

https://doi.org/10.1016/0958-6946(94)00037-9

[20] Kuma, B., Derek, B., Getnet, K. and Kassa, B. (2012) Market Access and Dairy Value Chain Industry in Ethiopia: The Case of Wolaita Zone. PhD Dissertation, School of Graduate Studies of Haramaya University, 115 p.

[21] Bereda, A., Yilma, Z. and Nurfeta, A. (2013) Handling, Processing and Utilization of Milk and Milk Products in Ezha District of the Gurage Zone, Southern Ethiopia. Journal of Agricultural Biotechnology and Sustainable Development, 5, 91-98. https://doi.org/10.5897/JABSD2013.0206 